\title{
Impact of the Gamma Variant on the ICU Admission in a Hospital of the Autonomous City of Buenos Aires (CABA), Argentina
}

Veronica Mandich ( $\nabla$ veromandich2000@yahoo.com.ar)

Hospital General de Agudos Donacion Francisco Santojanni https://orcid.org/0000-0002-3045-1772

Daniel Chiacchiara

HOSPITAL SANTOJANNI

Marcelo Bravo

HOSPITAL SANTOJANNI

Antonio Pilipec

HOSPITAL SANTOJANNI

Santiago Grimaldi

HOSPITAL SANTOJANNI

Johnis Cotes

HOSPITAL SANTOJANNI

Victor Paniouk

HOSPITAL SANTOJANNI

Henry Arevalo

HOSPITAL SANTOJANNI

Oswaldo Escobar

HOSPITAL SANTOJANNI

Sebastian Perez Flach

HOSPITAL SANTOJANNI

Amilcar Herbas Pozo

HOSPITAL SANTOJANNI

Alejandro Aimar

HOSPITAL SANTOJANNI

Mario Vargas

HOSPITAL SANTOJANNI

Karina Sañudo

HOSPITAL SANTOJANNI

Research Article 
Keywords: SEPTICEMIA, RESPIRATORY DIFFICULTY SYNDROME, SYSTEMIC INFLAMMATORY RESPONSE SYNDROME, COVID 19

Posted Date: December 3rd, 2021

DOI: https://doi.org/10.21203/rs.3.rs-997171/v4

License: (1) This work is licensed under a Creative Commons Attribution 4.0 International License. Read Full License 


\section{Abstract}

Purpose: Comparison between patients admitted to the Intensive Care Unit (ICU) with ventilatory support during the first and second wave (Gamma variant) of COVID 19 in a tertiary hospital in the City of Buenos Aires.

Method: Descriptive, observational, prospective cohort study in ICU of an acute general hospital in Argentina, with patients adult patients COVID-19 admitted consecutively to the ICU. The ICU the main variables of interest: Demographic and laboratory data, history, duration of MV, mortality.

Results: 44 patients were recruited during the first wave, and 80 in the second. Significant differences were observed in the second wave for age (60, [SD 11]; vs 68 [SD 11]; $p<0.01)$, days with symptoms (9 [SD 5]; vs 4.5 [SD 3]; $p$ <0.01), duration of MV (10 days [SD 7]; vs 16 [SD 13]; $p<0.01)$, Ferritin (1450 mcg / I [SD 547]; vs $941 \mathrm{mcg} /$ I [ SD 593]; p 0.04) and use of antibiotics ( $97 \%$ vs $45 \%$ p <0.01). There was no difference in mortality ( $66 \%$ vs $78 \% \mathrm{p} 0.14$ ) but there was in its primary causes; being more frequent hypoxemia associated with sepsis in the second wave $(40 \%$ vs $3.4 \% \mathrm{p}<0.01)$ and hypoxemia and multiorgan failure in the first $(28 \%$ vs $4 \% \mathrm{p}<0.01)$.

Conclusions: During the second wave of the pandemic, due to Gamma variant, more patients were admitted to our unit, younger, with a longer evolution time, a shorter time on MV and a greater inflammatory response, with no difference in mortality, although there was a difference in its causes.

\section{Introduction}

In the month of March 2020, the disease caused by a new coronavirus was declared a pandemic by the WHO; N-Covid19 [1,2]. Given its progress and the perspective of increased demand for health services in our country, following the example observed in other latitudes [2,3], the decision was made to increase the number of beds in ICUs [5-7]. To carry out this objective in hospitals, it was necessary to adapt rooms and services originally intended for other specialties. Such was the situation in our hospital, where the inpatient ward for patients discharged from the Coronary Unit became the new COVID ICU. This unit began receiving patients on June 1,2020 and continues to operate today.

During the first year of activity, the months of June, July, August and September 2020 were established as the first wave of the current pandemic; and as a second wave the months of April, May and June 2021. Throughout this year it became clear that the characteristics of both populations were different, which led to their description and analysis in the context of a public hospital of third level of the Autonomous City of Buenos Aires (CABA), Argentina, as a source of information on the evolution of the disease in a South American country.

The literature describes the dynamics of the current pandemic in the context of high-income countries [810], but information on its characteristics and evolution in low- and middle-income countries with less developed health systems is scarce [11] 
In addition, Latin America continues to be a place with a high number of cases, where new variants of the original virus such as 501Y.V3 (Gamma / Brazil) have been detected, whose impact on health systems in terms of demand, consumption and lethality deserve to be taken into account. into account [12-16].

In Argentina, in the period between the months of March and June 2021, an increase in the community circulation of the 501Y.V1 (Alpha / United Kingdom) and 501Y.V3 (Gamma/Brazil) strains was confirmed, with fluctuations of up to $27.1 \%$ for 501 Y.V1 and $31.3 \%$ for $501 Y . V 3$; only $2 \%$ of the sequences analyzed correspond to the circulating virus in the first wave. $[17,18]$. The objective of our study was to compare the patients admitted to our unit in said period (second wave) with those admitted during the months of June, July, August and September 2020 (first wave) [19].

\section{Methods}

A descriptive, observational study of a prospective cohort was developed on patients older than 18 years, with a confirmed diagnosis of COVID-19 by RT-PCR, consecutively admitted to the ICU. Two samples corresponding to First wave were selected: from June 1, 2020 to September 30, 2020 with 44 patients; and Second wave: from April 1, 2021 to June 30, 2021 with 80 patients; corresponding to the peak months of the pandemic in Argentina. (Figure 1)

The selection criterion was the admission of patients with ventilatory support requirements using MV or high-flow nasal cannula (HFNO: High Flow Nasal Oxygen) during the differentiated periods such as first wave and second wave; given that during the same, a greater work overload was identified in contrast to other months in the rest of the year. The HFNO resource was only available in the second wave.

Clinical, demographic and laboratory data were collected upon admission to the unit. The main objective was to compare demographic, clinical and laboratory characteristics between both groups.

The information was obtained from the medical records and the unit's database, through an anonymized Excel spreadsheet. Demographic data (age, sex, BMI), date of diagnosis, date of admission to hospital, date of admission to ICU, previous days with symptoms until admission to ICU, comorbidities, symptoms, $\mathrm{PaO} 2$ / FiO2, days of $\mathrm{MV}$, were recorded. days in the prone position, as laboratory parameters the following were obtained: percentage of lymphocytes, C-reactive protein (CRP), ferritin, D-dimer, procalcitonin $[20,21]$. In addition, the Sequential Organ Failure Assessment (SOFA) and Acute Physiology and Chronic calculations were performed. Evaluation II (APACHE II) The use of antibiotics, infections, tracheostomy requirements, hemodialysis, possibility of extubation were also recorded. The final outcome variable was death, recorded as a YES / NO binary variable. If so, the cause of death was also recorded.

Continuous variables were expressed as mean, standard deviation or median and interquartile range according to the distribution of the data with evaluation of the Shapiro-Wilk test of normality and the categorical variables, as absolute frequency and percentage. For the comparison of variables between the first and second waves, Pearson's Chi-Square or Fisher's exact test for categorical variables, non- 
parametric tests, Median test or Mann-Whitney test and t-test were used as statistical tests. Student's test for the numerical variables as appropriate by the distribution of the data. A level $p<0.05$ was considered significant. All analyzes were developed using the statistical program SPSS statistics version 20 . The primary, secondary and tertiary cause of death was compared by post hoc analysis, with Bonferroni adjustment.

The incidence of admissions to our ICU in each period was calculated using COVID-19 cases admitted to public hospitals in the city of Buenos Aires as the denominator [22]. Subsequently, their comparison was analyzed with statistical significance.

The present study was conducted without funding.

This study is registered in the Health Research Informatics Registry Platform (PRIISA) of the Government of the Autonomous City of Buenos Aires code 5258. Given its descriptive and observational nature, the application of informed consent was not required. The sources of information used were archival medical records and the service database.

Data anonymization was guaranteed by using a numerical coding system for patients.

\section{Results}

A total of 124 patients admitted to the COVID ICU of our hospital were enrolled; 44 consecutive patients enrolled as First Wave during the months of June, July, August and September 2020. Later, 80 patients consecutively enrolled as Second Wave were selected in the months of April, May and June 2021. All patients were older than 18 years, with a confirmed diagnosis of COVID-19 and admitted consecutively.

All the patients recruited during the first wave required MV, while, during the second wave, 15 of the 80 recruited patients required HFNO at the beginning, and of these $5(33 \%)$, they subsequently had to be connected to MV. (Table I)

In the second wave, there was an incidence of 69 admissions to ICU Santojanni / 100,000 admissions to public hospitals in CABA; while during the first wave the incidence was 11/100 000; This implies an increase in the incidence of admission to our ICU of 57.79 (95\% Cl 39.22-76.35) cases per 100,000 cases admitted to public hospitals in the city of Buenos Aires. (Figure 2) The patients in the second wave were significantly younger than those in the first wave ( 60.5 years VS. 68.5 years $p<0.01$ ); no differences in terms of gender distribution or BMI. The number of previous days with symptoms compared to ICU admission was higher in the second wave ( 9 vs $4.5 ; p<0.01$ ). Regarding the source of contagion, the unknown origin was significantly higher in the second wave $(78.9 \%$ vs $55.8 \%$; $<<0.01)$.

The presentation of the disease differed in terms of the frequency of dyspnea, being the prevalent symptom in the second wave ( $83.5 \%$ vs $56.8 \%, \mathrm{p}<0.01)$, without significant differences between other symptoms categorized as respiratory and muscular. 
Comorbidities such as hypertension, diabetes, obesity, and smoking did not show significant differences between the two populations; but the history of cardiovascular disease ( $29.5 \%$ vs $15.2 \%$; p 0.05$)$ and diagnosis of chronic obstructive bronchial disease (COPD) $(27.3 \%$ vs $8.9 \% ; p<0.01)$ did so in the first wave compared to the second). Contrary to other previous pathologies, such as HIV, hypothyroidism, or diagnosis of oncohematological disease; they were more frequent in the second wave ( $43 \%$ vs $22.7 \% ; p=$ 0.02). (Table II)

Regarding the clinical characteristics and laboratory parameters, the following differences were found in the second wave: shorter MV time (10 days vs 16 days; $p<0.01)$ and higher Ferritin dosage $(1450 \mathrm{mcg} / \mathrm{I}$ vs $941.5 \mathrm{mcg} / \mathrm{l} ; \mathrm{p}<0.04)$. On the other hand, there were no significant differences in $\mathrm{PaO} 2$ / FiO2 values, D-dimer dosage, APACHE II scores, SOFA and days of prone decubitus. (Table III)

A significant difference was found in the use of antibiotics during the second wave in relation to the first $96.7 \%$ vs $45.5 \%, \mathrm{p}<0.01$.

Although no significant difference was demonstrated in terms of mortality in ICU between the second and first wave $78.3 \%$ vs $65.9 \% ; p=0.14$; By means of a post hoc analysis of multiple comparisons with Bonferroni adjustment, it was possible to detect a significant difference for causes of death $p<0.01$; being more frequent the association hypoxemia and multiorgan dysfunction (55.2\% / $27.6 \%$ vs $56 \%$ / $4 \%$ ) in the first wave; while hypoxemia and sepsis $(55.2 \%$ / $3.4 \%$ vs $56 \%$ / $40 \%)$ were during the second wave with a level of significance between groups $p=<0.05$.

Tracheostomy requirements ( $28 \%$ second wave vs $29 \%$ first wave) and hemodialysis [23] (20\% second wave vs $11 \%$ ) did not show significant differences between the two waves. (Table IV)

\section{Discussion}

The data obtained confirm the assumption that in both waves the characteristics of the patients were different. During the second wave, when Gamma variant has been predominant, the incidence of cases in our ICU was much higher, which translated into work overload.

In this period, the admitted patients were younger, with a longer previous evolution time, and a greater inflammatory response, although this did not translate into significant changes in the $\mathrm{PaO} 2$ / $\mathrm{FiO} 2$, APACHE II or SOFA values.

The increase in the period of time until admission to the ICU is possibly due to the overload of the system and the lower availability of hospitalization in critical care.

The lack of significance between the severity scores may be biased by the strategy of early admission of the patients implemented in the middle of the second wave, for the performance of non-invasive ventilatory support with a high flow oxygen nasal cannula; resource that was not available during the first wave of the pandemic. 
Another significant data was that the antecedents related to cardiovascular diseases and EBOC were predominant in the first wave, while in the second other comorbidities (HIV, hypothyroidism) were significant.

Symptoms on admission also show significant changes, since the appearance of dyspnea was predominant during the second wave, to the detriment of symptoms such as dysgeusia or anosmia.

In relation to the evolution of the patients, the MV time was significantly shortened in the second wave, showing no changes in the days of prone decubitus, tracheostomy or hemodialysis requirements.

The increase in the use of antibiotics is consistent with the significant difference in sepsis as a cause of death found in the second wave, despite not finding differences between the two periods in mortality from ICU.

These data coincide with the increase in the circulation in our country of the 501Y.V3 strain, responsible for several outbreaks that occurred in Brazil, a phenomenon documented through the weekly epidemiological report carried out by the PAIS project of the National Ministry of Health. We sent samples from several patients during the second wave for genomic sequencing, being able to document positive results for the Gamma variant in at least two of them.

These data are consistent with research carried out in other countries, confirming changes in the profile of affected patients in each epidemic wave, although without significance in intra-ICU mortality. Although there are studies that identify differences between populations [24-27], these are not always in the same sense. A study carried out in Spain shows that the patients in the second wave were greater (n: 160 vs n: 68 in the second wave vs the first) and older (66 vs 60 respectively) and less severe (ferritin 1082 SD 855 ; vs 1506 SD 1082 in the second vs first wave), while in France a study was carried out that documented a lower requirement for $\mathrm{MV}$ and complications during the second wave, with patients being significantly younger in the second wave compared to the first ( 39 vs 45 ) with lower severity markers (D-dimer 0.6 vs $1.1 \mathrm{mcg} / \mathrm{I})$. Our research reveals differences between the patients of each epidemic wave in the geographical area of the city of Buenos Aires, and how these translate into an increase in the workload in the health systems. More and younger patients are admitted, with the same level of severity, which has not yet translated into a significant increase in mortality in the ICU. However, a fundamental fact is the increase in the use of antibiotics and the increase in sepsis as a cause of death [28-31], a phenomenon closely related to the increase in bacterial resistance that has already begun to be evidenced in several studies [32-34] and deserves to develop future lines of research and work guidelines in the field of the UCl.

These challenges ahead make the continuous strengthening of the health system essential, the permanent improvement of working conditions to mitigate the impact of each new wave on personnel in critical areas, as well as epidemiological surveillance for the early detection of new variants and jobs. research to demonstrate changes in the profiles of affected patients and their possible consequences.

\section{Conclusion}


The current Covid 19 pandemic evolves in successive waves, which lead to changes in patient profiles causing new challenges and impact on the health system and treating professionals; it is necessary to identify these changes in order to strengthen them and avoid new problematic situations such as the increased use of antibiotics and the emergence of bacterial resistance.

\section{Declarations}

FOUNDING:

Without financing

AUTHORS` CONTRIBUIONS:

DCh, MB and VM participated in the design of the study, and interpretation of the data. AP, SG, JC, VP, HA, $\mathrm{OE}, \mathrm{SPF}, \mathrm{AHP}$ and $\mathrm{AA}$ participated in the data collection and writing of the manuscript.

All authors read and approved the final manuscript.

COMPETING INTERESTS:

The authors declare that they have no conflict of interest

CONSENT FOR PUBLICATION:

The authors declare give their consent for publication

ACKNOWLEDGEMENTS:

Not applicable

ETHIC APPROVAL AND CONSET TO PARTICIPATE:

Not applicable

AVAILABILITY OF DATA AND MATERIAL:

Data sets during and / or analyzed during the current study are available from the corresponding author upon reasonable request.

\section{References}

1-WHO. WHO coronavirus disease (COVID-19) dashboard. https://covid19.who.int/ (accessed Feb 9, 2021). 
2- World Health Organization. Coronavirus disease 2019 (COVID-19): situation report181. Published July 19, 2020. https://www.who.int/docs/default-source/coronaviruse/situation-reports/20200719-covid-19sitrep-181.pdf?sfvrsn=

823524962 [accessed 20.07.20].

3- J. Xie, Z. Tong, X. Guan, B. Du, H. Qiu, A.S. Slutsky. Critical care crisis and some recommendations during the COVID-19 epidemic in China. Intensive Care Med., (2020), http://dx.doi.org/10.1007/s00134020-05979-7

4- P. Rascado Sedes, M.A. Ballesteros Sanz, M.A. Bodí Saera, L.F. Carrasco Rodríguez-Rey, A. Castellanos Ortega, M. Catalán González, C. de Haro López, et al. Plan de contingencia para los servicios de medicina intensiva frente a la pandemia COVID-19. Medicina Intensiva, Vol. 44. Numero 6 (2020) pp 363-370. DOI: 10.1016/j.medin.2020.03.006

5- Kirby T. South America prepares for the impact of COVID-19. Lancet Respir Med 2020; 8: 551-52.

6- Arias-López M, Mandich V, Mosciaro M, Ratto M, Chaparro Fresco J, Gallesio A, et al. Recomendaciones para la gestión de recursos en las Unidades de Cuidados Intensivos durante la pandemia de Covid-19. Medicina (Buenos Aires) 2020; Vol. 80 (Supl. iii): 67-7. ISSN 1669-9106

7- G. Grasselli, A. Pesenti, M. Cecconi. Utilización de cuidados críticos para el brote de COVID-19 en Lombardía, Italia: experiencia temprana y pronóstico durante una respuesta de emergencia. JAMA., (2020), http://dx.doi.org/10.1001/jama.2020.4031

8- Huang C, Wang Y, Li X, et al. Características clínicas de pacientes infectados con el nuevo coronavirus de 2019 en Wuhan, China. Lancet 2020; DOI: https://doi.org/10.1016/S0140-6736(20)30183-5

9- M.G. Argenziano, S.L. Bruce, C.L. Slater, J.R. Tiao, M.R. Baldwin, R. Graham, et al.

Characterization and clinical course of 1000 patients with COVID-19 in New York: retrospective case series. BMJ 2020; 369 doi: https://doi.org/10.1136/bmj.m1996

10-X. Yang, Y. Yu, J. Xu, H. Shu, J. Xia, H. Liu, et al. Clinical course and outcomes of critically ill patients with SARS-CoV-2 pneumonia in Wuhan, China: a single-centered, retrospective, observational study. 
Lancet Respir Med, 8 (2020), pp. 475-481

http://dx.doi.org/10.1016/S2213-2600(20)30079-5

11-Estenssoro, E MD; Loudet, C MD; Ríos, F MD; Kanoore Edul, V PhD; Andrian, M MD; Mandich,V MD et al.

Características clínicas y resultados de los pacientes con COVID-19 con ventilación invasiva en Argentina (SATICOVID): un estudio de cohorte prospectivo y multicéntrico

Lancet Respir Med 2021Publicado: 2 de julio de 2021DOI: https://doi.org/10.1016/S22132600(21)00229-0

12- Azurmendi P. ¿Hay variantes genéticas que puedan modificar el curso de la pandemia por COVID-19? Medicina (B Aires) 2020; Vol. 80 (Supl. III): 79-81

13- Aníbal A. Teherán, Gabriel Camero Ramos, Ronald Prado de la Guardia, Carolina Hernández, Giovanny Herrera, Luis M Pombo et al.

Caracterización epidemiológica de portadores asintomáticos de COVID-19 en Colombia: un estudio transversal. BMJ Open Dec 2020, 10 (12) e042122; DOI: 10.1136 / bmjopen-2020-042122

14- The Lancet. COVID-19 in Latin America: a humanitarian crisis.

Lancet 2020; 396: 1463.

15- Ñamendys-Silva SA, Gutiérrez-Villaseñor A, Romero-González JP. Hospital mortality in mechanically ventilated COVID-19 patients in Mexico. Intensive Care Med 2020; 46: 2086-88.

16- Ranzani OT, Bastos LSL, Gelli JGM, et al. Characterisation of the first 250000 hospital admissions for COVID-19 in Brazil: a retrospective analysis of nationwide data. Lancet Respir Med 2021; 407-18. 
17- Proyecto PAIS, MINCYT, Argentina. Reporte $N^{\circ} 20$ : Actualización Vigilancia de variantes de SARS-CoV2. En: https://www.argentina.gob.ar/noticias/nuevo-informede-proyecto-pais-sobre-vigilancia-devariantes-de-sarscov-2; consultado 15 mayo 2021

18- Proyecto PAIS, MINCYT, Argentina. Reporte $N^{\circ}$ 16: Actualización Vigilancia de variantes de SARSCoV-2. En: https://www.argentina.gob.ar/noticias/nuevo-informede-proyecto-pais-sobre-vigilancia-devariantes-de-sarscov-2; consultado 15 mayo 2021

19- Poder Ejecutivo Nacional. Aislamiento social, preventivo y obligatorio. Decreto $297 / 2020$. Boletín oficial de la República Argentina 2020; p. 7. https://www.argentina.gob.ar/normativa/nacional/decreto297-2020-335741/ actualizacion; consultado julio 2021.

20-Á. Estella, J.L. Garcia Garmendia, C. de la Fuente, J.F. Machado Casas, M.E. Yuste, R. Amaya Villar et al. Predictive factors of six-week mortality in critically ill patients with SARS-CoV-2: A multicenter prospective study. Medicina Intensiva Disponible online el 1 de Abril de 2021 DOI: 10.1016/j.medin.2021.02.013

21- J.M. Sirvent, A. Baro, M. Morales, P. Sebastian, X. Saiz. Predictive biomarkers of mortality in critically ill patients with COVID-19. Medicina Intensiva Disponible online el 13 de Diciembre de 2020. DOI: 10.1016/j.medin.2020.09.010

22-https://www.buenosaires.gob.ar/coronavirus/noticias/actualizacion-de-los-casos-de-coronavirus-enla-ciudad-buenos-aires; consultado julio2021

23- Y. Cheng, R. Luo, K. Wang, M. Zhang, Z. Wang, L. Dong, et al.Kidney disease is associated with inhospital death of patients with COVID-19.Kidney Int, 97 (2020), pp. 829838 http://dx.doi.org/10.1016/j.kint.2020.03.005

24-Fan G, Yang Z, Lin Q, Zhao S, Yang L, He D. Decreased case fatality rate of COVID-19 in the second wave: a study in 53 countries or regions. Transbound Emerg Dis. 2020, http://dx.doi.org/10.1111/tbed.13819. 
25- Contou D, Fraissé M, Pajot O, Tirolien JA, Mentec H, Plantefève G. Comparison between first and second wave among critically ill COVID-19 patients admitted to a French ICU: No prognostic improvement during the second wave? Crit Care. 2021; 4:3.

26-Gautret P, Colson P, Lagier JC, Camoin-Jau L, Giraud-Gatineau A, Boudjema S, et al. Different pattern of the second out-break of COVID-19 in Marseille, France. Int J Infect Dis. 2021; 102:17--9, http://dx.doi.org/10.1016/j.ijid.2020.10.005.

27- Iftimie S, López-Azcona AF, Vallverdú I, Hernàndez-Flix S, Febrer G, Parra S, et al. REUSCOVID Study Group. First and second waves of coronavirus disease-19: A comparative study in hospitalized patients in Reus, Spain. medRxiv 2020.12.10.20246959; https://doi.org/10.1101/2020.12.10.20246959.

28- J.Marin-Corral,S.Pascual-Guardia,R.Munoz-Bermúdez et al.,Health care-associated Infections in patients with COVID-19 pneumonia in COVID critical care areas, Medicina Intensiva, https://doi.org/10.1016/j.medin.2021.04.003.

29- C. Ferrando, R. Mellado-Artigas, A. Gea, E. Arruti, C. Aldecoa, R. Adalia, et al.

Patient characteristics, clinical course and factors associated to ICU mortality in critically ill patients infected with SARS-CoV-2 in Spain: a prospective, cohort, multicentre study. Rev Esp Anestesiol Reanim, 67 (2020), pp. 425-437

http://dx.doi.org/10.1016/j.redar.2020.07.003

30- H. Barrasa, A. Martín, J. Maynar, J. Rello, M. Fernández-Torres, A. Aguirre-Quiñonero, et al. High rate of infections during ICU admission of patients with severe SARS-COV-2 pneumonia: a matter of time? J Infect, 82 (2020), pp. 186-230

http://dx.doi.org/10.1016/j.jinf.2021.02.002

31-L. Lansbury, B. Lim, V. Baskaran, W.S. Lim.

Co-infections in people with COVID-19: a systematic review and meta-analysis.

J Infect, 81 (2020), pp. 266-275

http://dx.doi.org/10.1016/j.jinf.2020.05.046 
32- D. Contou, A. Claudinon, O. Pajot, M. Micaëlo, P. Longuet Flandre, M. Dubert, et al. Bacterial and viral co-infections in patients with severe SARS-CoV-2 pneumonia admitted to a French ICU. Ann Intensive Care, 10 (2020), pp. 119

33- A. Verroken, A. Scohy, L. Gérard, X. Wittebole, C. Collienne, P.F. Laterre, et al.

Co-infections in COVID-19 critically ill and antibiotic management: a prospective cohort analysis. Crit Care, 24 (2020), pp. 410 http://dx.doi.org/10.1186/s13054-020-03135-7 |

34- C. Garcia-Vidal, G. Sanjuan, E. Moreno-García, P. Puerta-Alcalde, N. Garcia-Pouton, M. Chumbita, et al. Incidence of co-infections and superinfections in hospitalized patients with COVID-19: a retrospective cohort study. Clin Microbiol Infect, 27 (2021), pp. 83-88 http://dx.doi.org/10.1016/j.cmi.2020.07.041

\section{Tables}

\section{TABLE 1: CLINICAL AND LABORATORY DATA OF PATIENTS WITH HFNO DURING 2nd WAVE}




\begin{tabular}{|c|c|}
\hline VARIABLES & PACIENTS WITH HFNO $2^{\text {nd }}$ WAVE \\
\hline $\mathrm{n}$ & 15 \\
\hline $\mathrm{Pa} / \mathrm{FiO} 2$ (mean, SD) & $128(28)$ \\
\hline SOFA (mean, SD) & $5,3(2)$ \\
\hline APACHE II (mean, SD) & $17(3)$ \\
\hline FERRITIN (mean, SD) & $1353 \mathrm{mcg}(466)$ \\
\hline
\end{tabular}

Values expressed as mean, SD (standard deviation)

Source: Self-made

TABLE 2: COMPARISON OF DEMOGRAPHIC DATA, BACKGROUND, SIGNS AND SYMPTOMS BETWEEN FIRST AND SECOND WAVE PATIENTS 


\begin{tabular}{|c|l|c|}
\hline $\begin{array}{c}\text { 1st } \\
\text { WAVE }\end{array}$ & 2nd WAVE & p \\
\hline 44 & 80 & \\
\hline $68,5(10)$ & $60,5(14)$ & $<0,01$ \\
\hline $31(70)$ & $54(67,5)$ & 0,73 \\
\hline $85(15)$ & $90(14)$ & 0,98 \\
\hline $31(5)$ & $31(5)$ & 0,56 \\
\hline$(4)$ & $9(6)$ & $<0,01$ \\
\hline
\end{tabular}

PREVIOUS DAYS WITH SYMPTOMS (MEDIUM, IQR)

\begin{tabular}{l|l|l}
$4,5(4)$ & $9(6)$ & $<0,01$
\end{tabular}

$\mathrm{n}$

AGE (MEDIUM, IQR)

MALE SEX (n, \%)

WEIGHT (MEDIUM, IQR)

BMI (MEDIUM, IQR)

H SYMPTOMS (MEDIUM, IQR)




\begin{tabular}{|l|l|l|l|} 
DYSNEA (n, \%) & $25(57)$ & $66(83,5)$ & $<0,01$ \\
\hline TOS (n, \%) & $25(57)$ & $34(43)$ & 0,14 \\
\hline ODINOFAGIA (n, \%) & $10(22)$ & $1(1,3)$ & $<0,01$ \\
\hline ANOSMIA/DYSGEUSIA (n, \%) & $3(6,8)$ & $5(6,3)$ & 0,92 \\
\hline DIARREHA, ABDOMINAL PAIN (n, \%) & $6(13,6)$ & $4(5)$ & 16 \\
\hline
\end{tabular}

Values expressed as mean, standard deviation (SD), median, interquartile range (IQR), $\mathrm{n}$ or\%.

Source: Self-made 


\begin{tabular}{|c|c|c|c|}
\hline VARIABLE & $1^{\text {a }}$ OLA & $2^{\mathrm{a}}$ OLA & $\mathrm{p}$ \\
\hline n & $\begin{array}{l}- \\
44\end{array}$ & 80 & - \\
\hline Pa/FiO2 (median; IQR) & $108,5(45)$ & $103,5(51)$ & 0,085 \\
\hline $\begin{array}{l}\text { DAYS in VM } \\
\text { (median; IQR) }\end{array}$ & $16(16)$ & $10(9)$ & $<0,01$ \\
\hline $\begin{array}{c}- \\
- \\
\text { Days in prone } \\
\text { (median; IQR) }\end{array}$ & $2(2)$ & $2(2)$ & 0,12 \\
\hline $\begin{array}{c}\text { SOFA } \\
\text { (median; IQR) }\end{array}$ & $8(4)$ & $10(3)$ & 0,17 \\
\hline APACHE II (mean; DS) & $22(5,8)$ & $22,4(4,8)$ & 0,72 \\
\hline $\begin{array}{c}\text { D-DIMER } \\
\text { (median; IQR) }\end{array}$ & $\begin{array}{c}3013,5 \mathrm{ng} / \mathrm{ml} \\
(4926)\end{array}$ & $2814 \mathrm{ng} / \mathrm{ml}(5936)$ & 0,71 \\
\hline $\begin{array}{c}\text { Ferritin } \\
\text { (median; IQR) }\end{array}$ & $941,5 \mathrm{mcg} / \mathrm{l}(869)$ & $1450 \mathrm{mcg} / \mathrm{l}(1004)$ & 0,04 \\
\hline
\end{tabular}

Values expressed as mean, standard deviation (SD), median, interquartile range (IQR), $\mathrm{n}$ or\%. MV: mechanical ventilation; SOFA: Sequential Organ Failure Assessment and APACHEII: Acute Physiology and Chronic Evaluation II. 
Source: Self-made

TABLE 4: COMPARISON OF RESULTS BETWEEN 1st AND 2nd WAVE PATIENTS

Page $18 / 21$ 


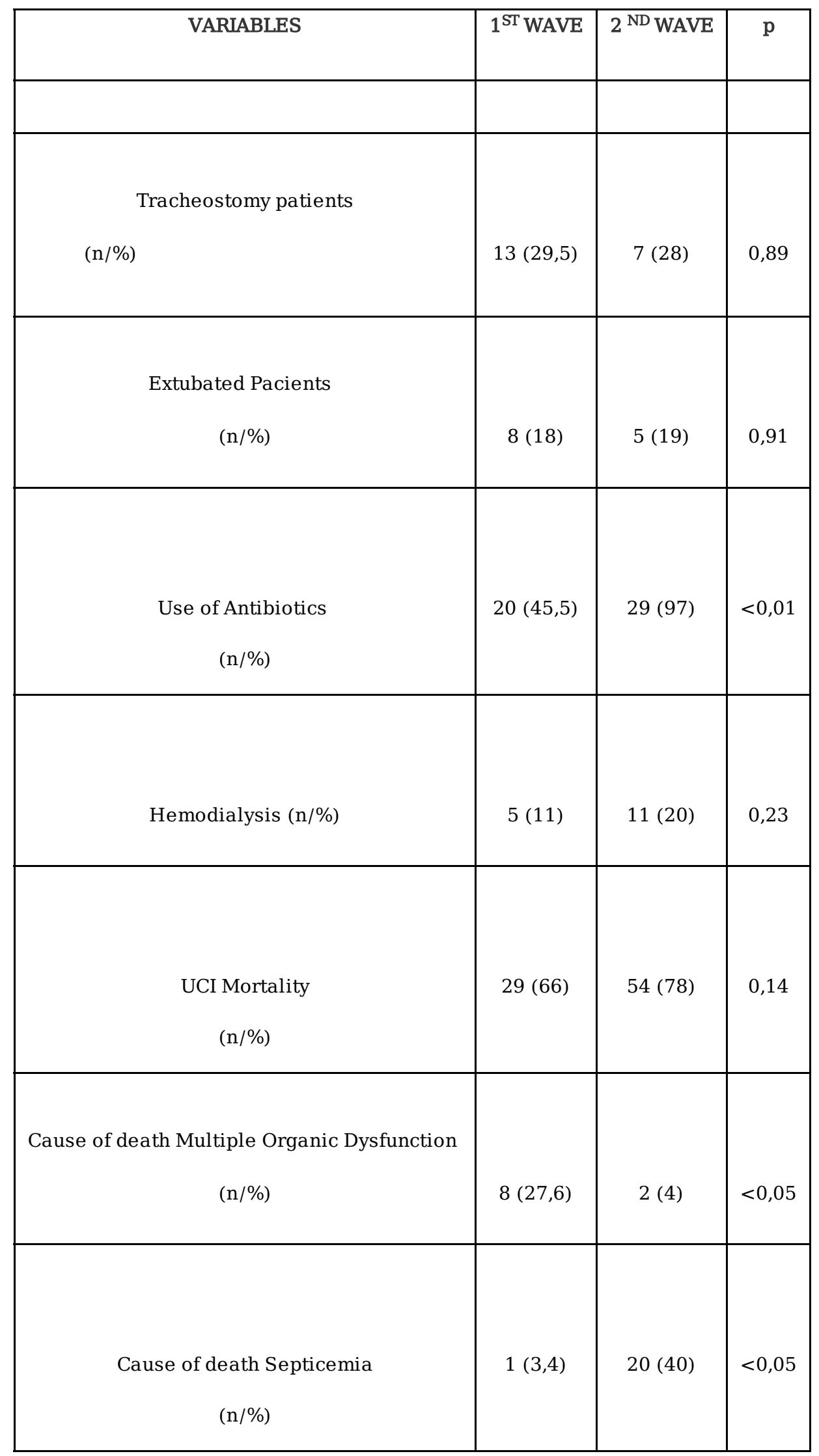

Variables expressed in $\mathrm{n}$ and\%

Source: Self made

Figures 


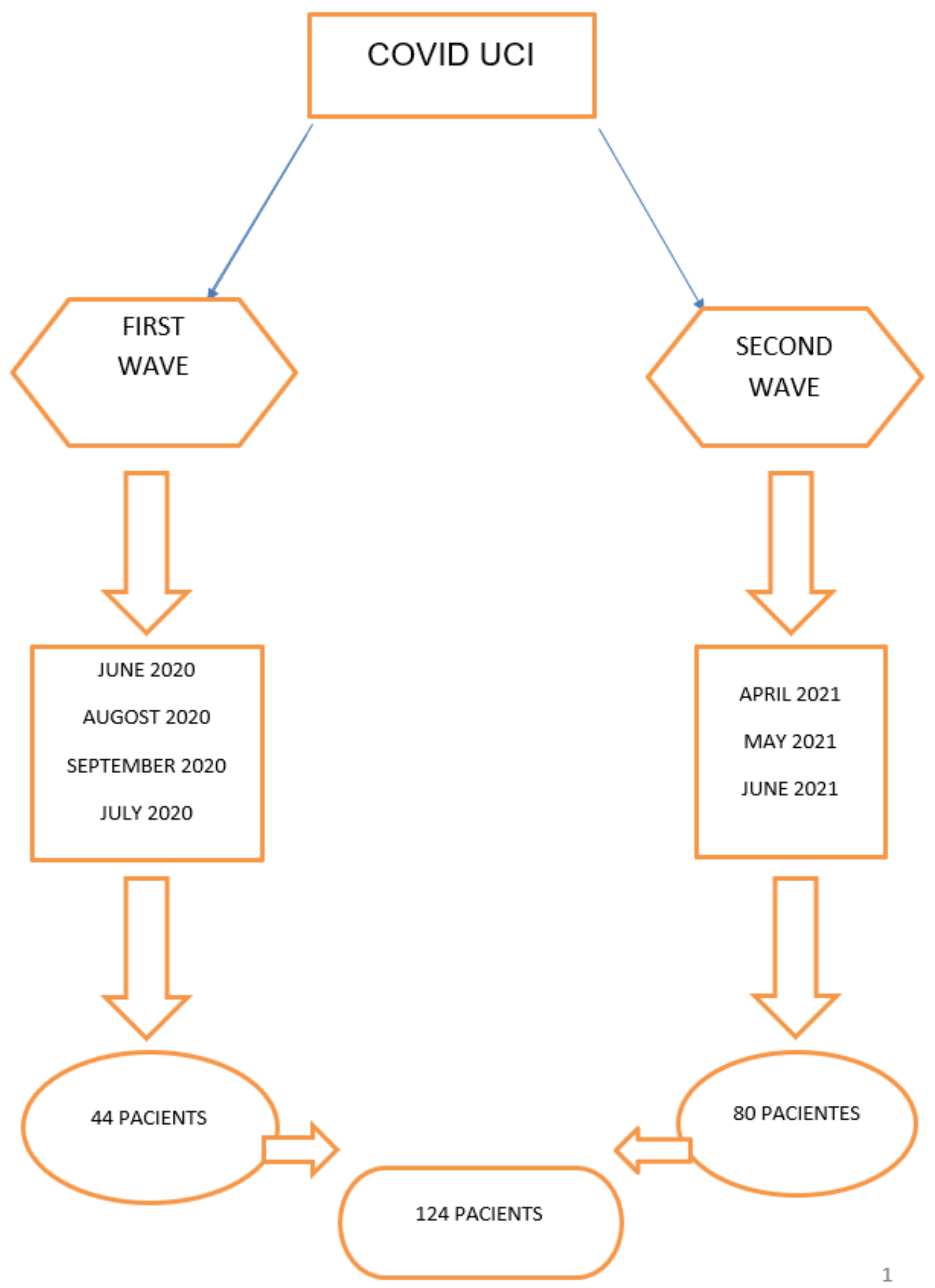

Figure 1

PACIENTS FLOWCHART 


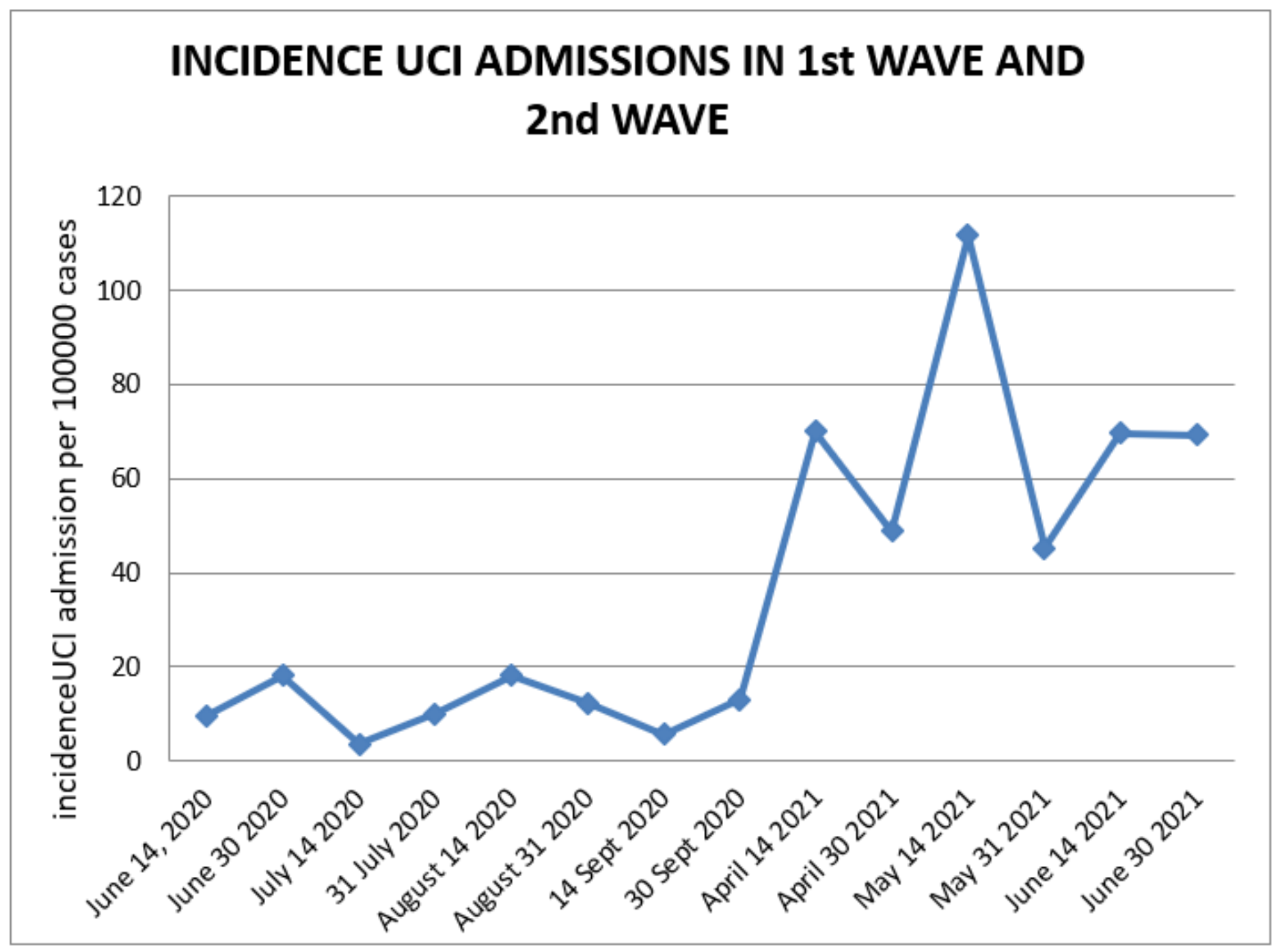

Figure 2

INCIDENCE UCI ADMISSIONS IN 1ST AND 2ND WAVES. Line graph showing the distribution of incidence of admissions to ICU of Santojanni hospital in the 1st wave and the 2nd wave for every 100,000 cases of Covid admitted to public hospitals in CABA in each month. Source: Self-made 